\title{
POLA KOMUNIKASI ANTAR PRIBADI MAHASISWA PAPUA DILINGKUNGAN UNIVERSITAS BENGKULU
}

\author{
Oleh: \\ SABARHATI MENDERITA LUMBAN GAOL, DEDI SUPRIADI, KHAIRIL \\ Program Studi Ilmu Komunikasi Fakultas Ilmu Sosial dan Ilmu Politik \\ Universitas Bengkulu
}

\begin{abstract}
This study aims to determine the interpersonal communication patterns of Papuan students who study at the University of Bengkulu. This study aims to explain more deeply the patterns of verbal and non- verbal communication between Papuan students through an in-depth interview process. The method used in this study is a qualitative descriptive method using De Vito's Theory (Humanistic Approach). The technique of collecting data is by conducting observations, in-depth interviews, and documentation. The results of this study indicate that Papuan students feel intimidated by the behavior they receive, this is the motive why Papuan students are rarely involved in social interaction and make distance between them and Bengkulu students, namely general distance because they feel insecure and uncomfortable when around Bengkulu students.
\end{abstract}

Keywords: communication patterns, interpersonal communication, papuan students, de vito's theory, campus environment

\section{PENDAHULUAN}

Tujuan nasional Negara Republik Indonesia yang tercantum dalam pembukaan UUD 1945 alinea keempat yang berbunyi "Kemudian daripada itu untuk membentuk pemerintahan Negara Indonesia yang melindungi segenap bangsa Indonesia dan seluruh tumpah darah Indonesia dan untuk memajukan kesejahteraan umum, mencerdaskan kehidupan bangsa, dan ikut melaksanakan ketertiban dunia yang berdasarkan kemerdekaan, perdamian abadi, keadilan sosial, maka disusunlah kemerdekaan kebangsaan Indonesia itu dalam suatu Undang-Undang Dasar Negara Indonesia, yang terbentuk dalam suatu susunan Negara Republik Indonesia yang berkedaulatan rakyat dengan berdasar kepada: Ketuhanan Yang Maha Esa, Kemanusiaan yang adil dan beradab, Persatuan Indonesia, dan Kerakyatan yang dipimpin oleh hikmat kebijaksanaan dalam permusyawaratan perwakilan, serta dengan mewujudkan suatu keadilan sosial bagi seluruh rakyat Indonesia ".

Pembukaan Undang-Undang Dasar tahun 1945 tersebut tercantumkan bahwa salah satu tujuan Negara Republik Indonesia adalah Mencerdaskan kehidupan bangsa. Terlepas dari hal itu pemerintah Indonesia berupaya melakukan pemerataan pendidikan untuk tercapainya jenjang pendidikan yang terbaik bagi seluruh rakyat indonesia, salah satunya adalah program beasiswa Afirmasi Pendidikan Tinggi dari Dikti (ADIK) kepada lulusan SMA sederajat yang berasal dari 
Papua, Papua Barat dan Daerah Terdepan, Terluar dan Tertinggal (3T). Beasiswa afirmasi ini diberikan kepada siswa-siswi lulusan SMA yang ingin melanjutkan pendidikan ke tingkat universitas di dalam maupun di luar negeri.

Hingga saat ini, jumlah putra-putri asli Papua yang dibiayai melalui program Beasiswa mencapai ribuan orang. Mereka menempuh pendidikan di hampir seluruh Perguruan Tinggi di Indonesia dan salah satunya adalah Universitas Bengkulu. Adanya kerjasama dengan pemerintah Papua yang memberikan beasiswa, serta publikasi yang efektif, citra yang sangat baik di matakhalayak luas dan visi-misi yang jelas, membuat Universitas bengkulu diminati para calon mahasiswa, baik dari dalam dan luar kota maupun luar provinsi. Begitu pula dengan mahasiswa yang berasal dari Papua yang akhirnya memilih Universitas bengkulu menjadi tempat menimba ilmu.

Menurut data hasil pra penelitian yang dilakukan peneliti terdapat 41 mahasiswa asal Papua yang sedang melanjutkan pendidikannya di Universitas Bengkulu dan tersebar di beberapa fakultas yaitu: 14 Mahasiswa Fakultas Ekonomi, 8 Mahasiswa Fakultas Pertanian, 4 Mahasiswa FISIP, 5 Mahasiswa FKIP, 7 Mahasiswa Fakultas Teknik, 3 Mahasiswa Fakultas Kedokteran. Mahasiswa Papua sebagai bagian dari makhluk sosial tidak terlepas dari kegiatan komunikasi. Komunikasi merupakan hal paling mendasar yang wajib dikuasai untuk dapat bertahan hidup guna berinteraksi dengan lingkungan sekitarnya. Mahasiswa Papua sebagai mahasiswa yang berasal dari daerah yang berbeda yang tentu saja membawa kebudayaan yang berbeda terkhusus cara berkomunikasi. Perbedaan ini disebabkan latar belakang yang merupakan hasil dari interaksi maupun budaya serta lingkungan.

Perbedaan fisik yang mencolok diantara mahasiswa Papua dengan mahasiswa lainnya di Universitas Bengkulu menjadi pusat perhatian khusus. Mahasiswa Papua secara umum memiliki warna kulit hitam legam rambut ikal- kribo, ekspresi muka kadang kaku, dan cenderung tidak berbaur. Menurut (Nabella 2013:3) mahasiswa Papua melakukan proses komunikasi antarpribadi secara intensif hanya dengan kalangan mereka, atau dengan kata lain mereka sangat jarang melakukan proses komunikasi dengan mahasiswa non-Papua. Hal ini disebabkan oleh perasaan terasingkannya mereka oleh pengaruh perbedaan suku, ras atau kebudayaan dan bahasa pada suatu tempat yang barudikunjungi.

Didalam konteks komunikasi yang memiliki latar belakang budaya yang berbeda tentu sangat diperlukan kecakapan dalam berkomunikasi, dan kemauan untuk mencoba bergaul dengan orang yang berlain budaya karena menurut Mulyana (Lusiana 2012:92) di Indonesia seringkali menggeneralisasikan streotip- streotip kesukuan misalnya, orang Jawa dan Sunda beranggapan bahwa mereka halus dan sopan dan bahwa orang Batak itu kasar, nekad dan suka berterusterang, pintar, rajin, kuat dan tegar. Apa yang orang Jawa dan Sunda anggap kekerasan dan kekasaran, bagi orang Batak adalah justru kejujuran dan keterusterangan., apa yang dianggap halus dan lembut oleh orang Jawa dan Sunda bagi orang Batak adalah kemunafikan dan kelemahan.

Begitu juga dengan mahasiswa Papua dalam berkomunikasi masih menggunakan Dialek bahasa daerahnya sehingga sering dianggap tidak fasih dalam berbahasa indonesia juga, adanya dugaan-dugaan yang cenderung meremehkan terhadap mahasiswa Papua.

Ketika kita berkomunikasi dengan orang lain dari suku agama, ras lain kita dihadapkan dengan sistem dan aturan yang berbeda, sehingga akan sulit memahami komunikasi mereka bila kita sangat etnosentrik. Hal ini mengakibatkan terasingkannya seseorang tanpa tau sisi pribadi orang tersebut. Disisi lain perkembangan hubungan manusia dewasa 
ini memberikan dampak pada cara manusia berkomunikasi. Hal tersebut disebabkan kedekatan seseorang dengan orang lain bukan hanya dilihat dari pesan yang disampaikan akan tetapi juga dari proses dan cara berkomunikasi yang diterapkan pada setiap individu. Adanya proses penyampaian pesan dari pemberi pesan (komunikator) kepada penerima pesan (komunikan) disebut dengan komunikasi.

Menurut Onong (2016:9) istilah komunikasi dalam bahasa Inggris communication berasal dari kata Latin communicati, dan bersumber dari kata communis yang berarti sama. Sama yang dimaksud adalah persama makna antara komunikator dengan komunikan. Persamaan makna yang terjadi antara dua orang dikenal dengan nama komunikasi interpersonal atau komunikasi antar pribadi. Komunikasi antar pribadi menurut Deddy Mulyana (Suranto Aw 2011:3) adalah komunikasi antara orang-orang yang berlangsung secara tatap muka dan yang memungkinkan setiap pesertanya menangkap reaksi orang lain secara langsung baik secara verbal maupun nonverbal.

Komunikasi antar pribadi yang terus berkesinambungan dapat membentuk sebuah pola yang menjadi proses dalam berkomunikasi beserta komponen lainnya. Pola Komunikasi diartikan sebagai bentuk atau pola hubungan dua orang atau lebih dalam proses pengiriman dan penerimaan cara yang tepat sehinggapesan yang dimaksud dapat dipahami. Komunikasi antar pribadi pada hakekatnya mempunyai pola yang menghubungkan antara komunikator dengan komunikan. Begitu pula dengan proses komunikasi antara mahasiswa Papua dan mahasiswa asal Bengkulu dalam interaksi dilingkungan Universitas Bengkulu yang menjadi rutinitas sehari-hari. Bentuk kebiasaan dari cara berkomunikasi mempunyai dampak bagi penerima pesan, setiap orang mempunyai pola yang berbeda akan tetapi pola tersebut dapat dibentuk sesuai dengan arah dan sasarannya.

\section{METODE PENELITIAN}

Tipe penelitian ini adalah penelitian kualitatif yang bersifat deskriptif. Metode penelitian deskriptif kualitatif adalah metode penelitian yang digunakan untuk meneliti pada kondisi obyek yang alamiah yaitu yang berkembang apa adanya, tidak dimanipulasi oleh peneliti dan kehadiran peneliti tidak mempengaruhi dinamika pada obyek tersebut, serta berusaha menggambarkan kejadian atau fenomena yang sedang berlangsung, telah berlangsung atau yang akan berlangsung.

Teknik pengumpulan data untuk memperoleh data atau informasi dan keterangan-keterangan yang diperlukan, maka peneliti menggunakan teknik pengumpulan data. Adapun jenis data yang digunakan dalam penelitian ini, yaitu: Data primer yang diperoleh berasal dari hasil penelitian dilapangan. Dimana dalam penelitian ini teknik pengumpulan data menggunakan metode yang terdiri dari observasi, wawancara mendalam, dan dokumentasi. Sedangkan data sekunder yang digunakan peneliti berasal dari buku, penelitian-penelitian terdahulu, maupun pustaka online yang berhubungan dengan pola komunikasi antar pribadi.

Setelah data-data yang dibutuhkan dalam penelitian terkumpul maka tahap selanjutnya adalah analisis data. Teknik analisis data yang digunakan peneliti adalah teknik analisis data model Miles dan Huberman. Dalam teknik analisis data tersebut menurut (Ulber silalahi, 2009:339) terdiri dari tiga alur kegiatan yaitu : reduksi data, penyajian data, dan menarik kesimpulan/verifikasi.

\section{HASIL PENELITIAN DAN PEMBAHASAN}

Dari pengamatan yang dilakukan, peneliti memfokuskan pembahasan pada 2 (dua) pola komunikasi yang sering digunakan oleh mahasiswa Papua di lingkungan Universitas Bengkulu, yaitu komunikasi verbal (bahasa) dan 
nonverbal (kinesics, paralanguage dan proxemics).

\section{Komunikasi Secara Verbal Mahasiswa Papua di Universitas Bengkulu}

Dari banyak faktor kebudayaan yang mempengaruhi komunikasi mahasiswa Papua dengan mahasiswa lokal di Universitas Bengkulu, salah satunya adalah bahasa. Kurangnya kemampuan mahasiswa papua dalam berbahasa Indonesia yang baik, dimana mereka masih cukup kuat dalam membawa bahasa daerah mereka maka dari itu dialek bahasa mereka ketika berkomunikasi sedikit sulit untuk dipahami. Permasalahan lain muncul ketika mahasiswa lain di Universitas Bengkulu lebih sering menggunakan bahasa lisan informal, sedangkan yang mereka pelajari adalah bahasa Indonesia tulis dan formal. Selain bahasa informal, tempo bicara mahasiswa lokal dinilai terlalu cepat. Eksistensi bahasa Bengkulu diakui sedikit mengganggu proses adaptasi. Perbedaan bahasa dan dialek yang digunakan oleh mahasiswa Papua, menjadi suatu hambatan ketika melakukan proses komunikasi dengan mahasiswa non-Papua yang menggunakan bahasa dan dialek Bengkulu. Perbedaan bahasa yang membentang membuat mahasiswa Papua sulit menjalin komunikasi yang akhirnya membuat mereka menutup diri.

Sebelum datang ke Bengkulu 6 (enam) informan merupakan lulusan SMU dari provinsi papua dan papua barat yang sama sekali tidak pernah mengetahui Universitas Bengkulu. Hal tersebut membuat mereka cukup kesulitan saat pertama kali tiba di Provinsi Bengkulu, khususnya di Kota Bengkulu, yaitu kota yang akan mereka tinggali selama menempuh pendidikan di Universitas Bengkulu yang mayoritas penduduknya lebih banyak menggunakan dialek dan bahasa Bengkulu untuk kesehariannya. Hal tersebut melatar belakangi penggunaan bahasa verbal dan sekaligus bahasa nonverbal oleh mahasiswa asal Papua untuk dapat berkomunikasi dengan mahasiswa lokal saat awal mereka tiba di Bengkulu.

Tidak bisa dipungkiri, kebiasaan mahasiswa Bengkulu lebih sering menggunakan bahasa lisan dan informal (bahasa Bengkulu) membuat beberapa dari mereka malas berkomunikasi, seperti Maria yang kurang memahami bahasa dan dialek Bengkulu sering merasa tidak dihargai ketika berbicara, sehingga memilih untuk menarik diri. Maria masih sangat kesulitan untuk memahami dialek Bengkulu, selain itu bahasa Indonesia yang digunakannya masih didominasi dialek Papua. Bahasa yang tidak dikuasai dengan baik oleh Maria, membuatnya terintimidasi dan terisolir oleh lingkungan sekitar, karena sulitnya melakukan komunikasi dengan sekitarnya. Tapi hal tersebut justru menjadi motivasi bagi 5 mahasiswa Papua yang lain untuk mengasah kemampuan berbahasa mereka baik bahasa Indonesia maupun Bengkulu.

Motivasi diri, pergaulan dan proses komunikasi antar budaya dengan teman, penduduk lokal, membuat kendala bahasa lambat laun bisa diatasi. Sedikit demi sedikit mereka mulai mengerti ungkapan dalam bahasa Bengkulu. Proses komunikasi yang sering dilakukan membuat kendala dalam berbahasa dapat diatasi, terlebih Sarina yang berkuliah di Fakultas Teknik yang dikenal dengan solidarits mahasiswa yang sangat erat menjadikan motivasi untuk dapat lebih menguasai dan mengerti ungkapan dalam bahasa Bengkulu.

Perbedaan durasi tinggal di Indonesia menjadikan kemapuan bahasa Indonesia setiap individu mahasiswa Papua juga berbeda. Kebanyakan mahasiswa baru, yang baru 1 tahun sejak tiba di Bengkulu seperti Sarina, Agnes dan Maria masih terlihat sangat jelas bahwa lambang nonverbal masih lebih mendominasi saat mereka berkomunikasi dengan mahasiswa lokal. Kemampuan bahasa Indonesia yang belum cukup baik, membuat mereka lebih banyak 
menggunakan komunikasi verbal dalam bahasa Indonesia dengan dialek Papua lalu diikuti dengan lambang non verbal. Dua mahasiswa Papua lain yang sudah lebih lama tinggal di Bengkulu kurang lebih 2 tahun, yaitu Marsel dan Pince memiliki kemampuan yang lebih baik dalam berkomunikasi dengan mahasiswa lokal. Mereka menggunakan komunikasi verbal lebih banyak dibanding dengan komunikasi non verbal. Meski sesekali mereka menyelipkan kata dialek bahasa daerah di dalam kalimat bahasa Indonesia yang mereka utarakan, hal tersebut tidak menjadi kendala yang berarti untuk kedua belah pihak, baik mereka (mahasiswa Papua) dengan mahasiswa lokal.

Berbeda dengan mereka ber-5, Sarah bisa dibilang sudah sangat mahir berbahasa Indonesia dibandingkan dengan kemampuan bahasa Indonesia mahasiswa Papua yang lain. Setelah kurang lebih tinggal selama 5 tahun di Bengkulu, membuatnya sudah sangat terbiasa dengan bahasa Indonesia dan dialek Bengkulu, sehingga jarang sekali menjumpai sarah berkomunikasi dengan mahasiswa lokal menggunakan lambang nonverbal, hampir seluruhnya menggunakan lambang verbal dalam bahasa Indonesia. Tetapi selama berkuliah kurang lebih 5 tahun Sarah sering menganggap dirinya tidak mampu, down. Hal- hal tersebut disebabkan karena mahasiswa Papua merasa malu dan minder dengan tingkat pengetahuan mereka yang berbeda dengan mahasiswa lainnya di Universitas Bengkulu. Sehingga hal tersebut menjadi penghambat mahasiswa papua untuk percaya diri dalam berkomunikasi.

\section{Komunikasi Secara Non Verbal Mahasiswa Papua di Universitas Bengkulu}

Proses komunikasi tidak selalu disampaikan dengan komunikasi verbal saja, tetapi ada komunikasi yang disampaikan juga bersamaan dengan komunikasi non verbal. Komunikasi nonverbal dapat mempertegas pesan yang disampaikan secara verbal. Secara garis besar bahwa komunikasi non verbal terbagi menjadi tiga yakni kinesik, proksemik, dan paralinguistik.

Komunikasi non verbal yang digunakan oleh mahasiswa Papua ketika melakukan proses komunikasi ialah menunduk yang bermakna malu atau minder, tidak percaya diri, terlihat gelisah, menggoyang-goyangkan kaki, tangan, jarang sekali menatap mata lawan bicara dan lain sebagainya. Hal ini didapat ketika peneliti melakukan wawancara mendalam dengan para informan. Selain itu volume mereka berbicara sangat pelan dan tidak lantang, lain halnya dengan Marsel ketika wawancara volume suara cukup tinggi sehingga pesan yang disampaikan cukup jelas. Jadi ketika mereka berkomunikasi tatap-muka mereka lebih memilih untuk tidak menatap mata lawan bicara mereka, menggoyanggoyangkan kaki, dan bertingkah laku seperti layaknya seseorang yang sedang gelisah dan terancam.

Selain itu, dengan adanya beberapa perlakuan kasar yang mereka terima dari mahasiswa Bengkulu membuat mereka lebih menutup diri dan memberi jarak yang lebih pada mahasiswa Bengkulu. Dari hasil wawancara mendalam yang didapat, mahasiswa Papua merasa terintimidasi oleh perilaku yang mereka terima, hal ini menjadi motif mengapa mahasiswa Papua jarang melakukan interaksi sosial dan membuat jarak antara mereka dan mahasiswa Bengkulu, yakni jarak umum karena mereka merasa tidak aman dan tidak nyaman ketika berada di sekitar mahasiswa Bengkulu.

Komunikasi antar pribadi merupakan salah satu upaya yang diterapkan mahasiswa papua dalam menjalin komunikasi dengan mahasiswa lainnya di UNIB. Agar terjadi komunikasi yang efektif diperlukan keterbukaan, empati, sikap mendukung, sikap positif, dan kesetaraan. Jika dikaikan dengan aspek-aspek komunikasi antar pribadi maka komunikasi antar pribadi mahasiswa Papua berperan dalam menjalin 
keakraban dengan mahasiswa Bengkulu. Berikut unsur dalam komunikasi antar pribadi menurut Devito dalam perspektif humanistik.

\section{Keterbukaan (Openness)}

Menurut Devito Sikap terbuka mendorong timbulnya pengertian, saling menghargai, dan saling mengembangkan hubungan antarpribadi. Kualitas keterbukaan mengacu pada tiga aspek dari komunikasi interpersonal, yaitu komunikasi yang efektif harus terbuka kepada orang yang diajak berinteraksi, kedua adanya kesediaan untuk bereaksi secara jujur terhadap stimulus yang datang, dan yang ketiga menyangkut adanya kepemilikan perasaan dan pikiran. Sikap keterbukaan ini berdasarkan hasil penelitian yang dilakukan, mahasiswa Papua cenderung terbuka apabila sudah merasa dekat dengan lawan bicaranya. Mereka berbagi ceritadengan mahasiswa yang dianggap dekat, ketika ada masalah keuangan, kendala dalam menyelesaikan tugas kuliah. Namun keterbukaan mahasiswa Papua belum sepenuhnya dilakukan hal ini diakibatkan adanya kekhawatiran akan dianggap remeh karena perbedaan intelektual, fisik dan bawaan mereka yang berbeda dan lain sebagainya. selain itu mahasiswa Papua kurang menggunakan bahasa dengan baik, mereka pun otomatis tidak dapat menyampaikan apa yang mereka rasa, mau dan ingin. Dan hanya dengan sesama merekalah, mahasiswa Papua dapat saling mengerti dan mencurahkan apa yang ingin mereka katakan.

\section{Empati}

Empati merupakan kemampuan seseorang untuk merasakan seandainya menjadi orang lain, dapat memahami sesuatu yang sedang dialami orang lain, merasakan apa yang dirasakan orang lain dan memahami sesuatu dari sudut pandang orang lain.

Dalam penelitian ini mahasiswa Papua selalu menunjukan sikap empati kepada teman perkuliahannya, apabila ada teman yang mengeluh, sedang kesulitan mereka miliki sikap yang mau mendengar, menerima keluhan, kemudian dapat mengerti serta merasakan apa yang juga dirasakan oleh teman yang sedang berkeluh kesah. Mereka berusaha menunjukan sikap perhatian terhadap setiap permasalahan yang dialami oleh temannya bahkan mereka mau memberi bantuan pinjaman kepada teman yang sedang kesulitan dalam ekonomi.

\section{Sikap Mendukung}

Hubungan antar pribadi yang efektif harus memiliki komitmen dan sikap untuk mendukung (supportiveness). Berdasarkan hasil penelitian diketahui sikap dari mahasiswa Papua jarang sekali memberi dukungan terhadap kegiatan- kegiatan yang dilaksanakan kampus maupun HIMA, Sebagian mereka hanya sekedar mengikuti, jarang sekali untuk terlibat dalam pelaksanaan. Alasan tidak tergabung adalah malas, ketidak nyamanan, mereka lebih memilih tergabung dan memberi dukungan dalam kegiatan yang dilaksanakan di organisasi Ikatan Mahasiswa Papua.

Hal ini berkaitan dengan dominasi dimana salah satu pihak berusaha mengendalikan pihak lain sehingga orang tersebut merasakan hak-haknya dilanggar. Salah satu pihak berada pada posisi selalu menang, sementara pihak lain selalu kalah. Salah satu pihak selalu mengatur, sementara pihak lain selalu tunduk. Ketika seseorang merasa tidak kuat pada posisi selalu kalah, didikte dan diatur, maka akan timbul keberanian pada dirinya untuk mengambil sikap yang realistis, yakni memutuskan hubungan.

\section{Sikap Positif}

Devito mengatakan sikap positif ditunjukan dalam bentuk sikap dan perilaku. Dalam bentuk-bentuk sikap, maksudnya adalah bahwa pihak-pihak yang terlibat dalam komunikasi interpersonal harus memiliki perasaan dan pikiran positif, bukan prasangka dan curiga. Dalam penelitian ini mahasiswa Papua cenderung mudah tersinggung, namun tersinggung masih dalam hal wajar, ini dikarenakan cara mahasiswa bengkulu yang sering mengikuti 
bahasa dan logat Papua, respon ketika Mahasiswa papua berbicara sering ditertawai oleh mahasiswa Bengkulu. Selain itu beberapa perlakuan maupun perkataan yang tampak menyakitkan didengar mahasiswa seperti perkataan yang menyinggung fisik seperti rambut keriting maupun kulit hitam, sering sekali membuat mereka tersinggung karena merasa seolah-olah dihina.

\section{Kesetaraan}

Kesetaraan berarti kita menerima pihak lain, kesetaraan meliputi penempatan diri setara dengan orang lain, menyadari akan adanya kepentingan yang berbeda, mengakui pentingnya kehadiran orang lain, tidak memaksakan kehendak, kemunikasi dua arah, saling memerlukan, serta suasana komunikasi akrab dan nyaman. Dalam suatu hubungan antarpribadi yang ditandai oleh kesetaraan, ketidak sependapatan dan konflik lebih dilihat sebagai upaya untuk memahami perbedaan yang pasti ada daripada hanya sebagai kesempatan untuk menjatuhkan pihak lain. Dalam penelitian ini mahasiswa Papua sering menganggap dirinya tidak setara dengan mahasiswa lainnya, terlebih dari segi akdemik mereka sering minder, takut tidak bisa bersaing. Mereka sering merasa tidak percaya diri untuk berbicara karena khawatir apa yang disampaikan tidak dipahami oleh lawan bicaranya.

Dari hasil-hasil yang telah dipaparkan di atas, pola komunikasi antarpribadi mahasiswa Papua di Universitas Bengkulu ialah pola komunikasi primer, yakni suatu proses penyampaian pikiran oleh komunikator kepada komunikan dengan menggunakan suatu lambang, yakni verbal atau bahasa yang paling sering digunakan karena mampu mengungkapkan pikiran seseorang, dan lambang non verbal yakni lambang yang digunakan dalam berkomunikasi yang bukan menggunakan bahasa melainkan isyarat dengan anggota tubuh. Dalam aspek-aspek efektifitas komunikasi antar pribadi dari sudut perspektif humanistik yaitu keterbukaan, empati, sikap mendukung, sikap postif, dan kesetaraan mahasiswa Papua belum sepenuhnya menerapkan aspek-aspek tersebut dalam komunikasi interpersonalnya dengan mahasiswa lainnya di Universitas Bengkulu. Sikap empati yang mereka terapkan tidak sepenuhnya menciptakan hubungan antar pribadi yang efektif dengan kata lain jarang sekali ada kedekatan antara mahasiswa Papua dengan Mahasiswa Bengkulu. Sehingga tujuan dari komunikasi antar pribadi belum sepenuhnya tercapai.

\section{PENUTUP \\ Kesimpulan}

Dari hasil penelitian dan pembahasan pada bab sebelumnya maka peneliti menyimpulkan sebagai berikut:

1. Komunikasi antarpribadi yang digunakan oleh mahasiswa Papua kurang efektif. Hal ini disebabkan oleh adanya gangguan yang menghambat proses komunikasi baik itu komunikasi verbal maupun komunikasi nonverbal. mahasiswa Papua kurang dalam menjelaskannya dengan menggunakan bahasa dan dialek Bengkulu agar mahasiswaBengkulu dapat mengerti apa yang mereka sampaikan. Selain itu, pada komunikasi non-verbal juga dapat dilihat bahwa mahasiswa Papua membuat suatu penghalang antara mereka dan mahasiswa Bengkulu, hal itu terlihat dari gerak tubuh, mimik wajah, sikap badan, volume suara, kecepatan juga beberapa hal lainnya yang membuat ketidaknyamanan dan ketidakamanan yang mengakibatkan ruang jarak pemisah terhadap mahasiswa Bengkulu Sehingga mahasiswa Papua menarik diri dan menutup diri dari lingkungan sekitar.

2. Efektivitas komunikasi antarpribadi mahasiswa Papua yang dapatdilihat dari kriteria efektivitas komunikasi antarpribadi berdasarkan kelima aspek 
humanistik yang diterapkan mahasiswa Papua dengan Mahasiswa Bengkulu tidak mampu dilakukan dengan baik.

\section{Saran}

Berdasarkan penelitian dan hasil analisis yang telah dilakukan peneliti ada beberapa hal yang harus diperhatikan sebagai masukan dan saran:

1. Mahasiswa Papua harus pandai dalam menyiasati perbedaan bahasa dan dialek, karena dengan begitu mereka dapat dengan mudah melakukan proses komunikasi dengan mahasiswa Bengkulu. sekalipun dengan menggunakan bahasa Indonesia yang baku agar kedua belah pihak mengerti dan mendapat satu pengertian bersama.

2. Mahasiswa Papua harus dapat menyesuaikan diri dalam komunikasi non verbal seperti volume suara, kecepatan,gerak tubuh, mimik harus diubah menjadi lebih baik lagi agar komunikasi antar pribadi lebih efektif

3. Mahasiswa Papua harus lebih terbuka, empati, selalu mendukung, selalu bersikap positif, bersikap setara dan percaya diri ketika berkomunikasi dengan mahasiswa lainnya di Universitas Bengkulu sehingga hubungan antar pribadi berjalan efektif.

4. Pentingnya saling memahami, mempelajari, dan menerima keunikan karakteristik dari tiap-tiap etnis dalam menambah wawasan serta menghindari timbulnya prasangka.

\section{DAFTAR PUSTAKA}

Aw, Suranto. 2011. Komunikasi Interpersonal. Yogyakarta, Graha Ilmu. Budyatna

Muhammad dan Leila, Mona Ganiem. 2011. Teori Komunikasi Antar Pribadi. Jakarta, Prenada Media Group.

DeVito, Joseph A. 1997. Komunikasi Antar Manusia. Jakarta, Profesional Books
Effendi, Onong Uchjana. 2005. Ilmu komunikasi Teori dan Praktek. Bandung, PT.Remaja Rosdakarya.

Efendi, Onong Uchajana. 2009. Ilmu Komunikasi, Teori dan Praktek. Bandung, PT.Remaja Rosdakarya.

Hidayat, Dasrun. 2012. Komunikasi Antar Pribadi dan Medianya. Yogyakarta, Graha Ilmu.

Lubis, Lusiana Andriani. 2012. Pemahaman Praktis Komunikasi Antar Budaya. Medan, USU Press

Mulyana, Deddy. 2001, Ilmu Komunikas Suatu Pengantar. Bandung, PT.Remaja Rosdakarya.

Silalahi, Ulber. 2010. Metode Penelitian Sosial. Bandung, PT.Refika Aditama.

Soejanto, Agoes, 2005. Psikologi Komunikasi. Bandung, PT. Remaja Rosdakarya.

Sugiyono. 2014. Metode Penelitian Kuantitatif, Kualitatif,dan $R \& D$. Bandung, Alfabeta.

Suyanto, Bagong dan Sutinah. 2005. Metode Penelitian Sosial. Jakarta, Kencana Prenadamedia Group.

Rundengan, Nabella. 2013. Pola Komunikasi Antarpribadi Mahasiswa Papua di Lingkungan Fakultas Ilmu Sosial dan Ilmu Politik Universitas Sam Ratulangi Manado. Acta Diurna, Volume II. No.I.

Novianti, Sondakh, dan Rembang . 2017. Komunikasi Dalam Menciptakan Harmonisasi (suami dan istri) Keluarga di Desa Sagea Kabupaten Halmahera Tengah. Acta Diurna, Volume VI. No.2. 
Jurnal Professional FIS UNIVED Vol.7 No.1 Juni 2020 